\title{
An Assessment of the Knowledge of Dentists on the Emergency Management of Avulsed Teeth
}

\section{Procjena znanja stomatologa o hitnom zbrinjavanju avulzija zuba}

\author{
${ }^{1}$ Department of Pediatric Dentistry, School of Dental Medicine, Bahcesehir University, Istanbul, Turkey \\ Zavod za pedodonciju Stomatološkog fakulteta Sveučilišta Bahcesehir, Istanbul, Turska \\ 2 Private Practice, Istanbul, Turkey \\ Privatna ordinacija, Istanbul, Turska \\ ${ }^{3}$ Department of Developmental and Preventive Sciences, School of Dentistry, Kuwait University, Kuwait \\ Odjel za razvojne i preventivne znanosti Stomatološkog fakulteta Sveučilišta u Kuvajtu, Kuvajt \\ ${ }^{4}$ Department of Pediatric Dentistry, School of Dentistry, Marmara University, Istanbul, Turkey \\ Zavod za pedodonciju Stomatološkog fakulteta Sveučilišta Marmara, Istanbul, Turska
}

\section{Abstract}

Objective: to investigate the knowledge and attitudes of general dental practitioners (GDPs) on the emergency management of avulsed teeth. The management of the avulsed teeth is well outlined in the latest trauma guideline. However, little information is available about the level of knowledge of the management of avulsed teeth among young dentists in Turkey. Material and Methods: A crosssectional questionnaire was completed to assess the knowledge of GDPs on the emergency management of avulsed teeth. The questionnaire asked questions to 142 dental practitioners about whether they have received information about the emergency management of dental trauma, whether they have intervened in cases of avulsed teeth following a dental trauma, and, finally, whether they have given treatment of avulsed teeth. Results: The majority of GDPs had received training to treat avulsed teeth. The findings of the study showed that only $35 \%$ of GDPs recalled the critical time for treatment. The number of GDPs who had incorrect knowledge on this topic was higher and statistically significant $(p<0.001)$. The rates of the correct answers according to the relevant information fields were as follows: optimal storage medium ( $78 \%$ ), type of splint (56\%), splinting period (58.5\%), and systemic medication after avulsion (32\%). Conclusion: The results show that many GDPs had limited experience in treating avulsed teeth. However, in the study, it was stressed that the knowledge of GDPs related to the factors affecting the successful treatment of avulsion cases should be improved by using continuing education programs.
Received: January 29, 2020

Accepted: May 9, 2020

Address for correspondence

Betul Sen-Yavuz

ORCID: 0000-0002-7561-8396

Bahcesehir University, School of

Dental Medicine

Department of Pediatric Dentistry

Istanbul, Turkey.

Phone: +90 5399887646

dtbetulsen@gmail.com

Key words

Dental Trauma; Tooth Avulsion; Emergency Treatment; Tooth Replantation; Health Knowledge Attitudes Practice; Dentist's Practice Patterns

\section{Introduction}

Dental injuries are a frequent health problem in pediatric populations (1). Avulsion, which is one of these traumatic injuries, is defined as the full removal of the tooth from its socket because of dental trauma (2).

The ideal treatment procedure to be followed in avulsion cases is to replant the tooth into its socket immediately, to implement the splinting technique, subsequently to observe carefully if there is a revascularization in cases with incomplete root development or endodontic treatment for the teeth that have completed their root development by keeping the tooth in the mouth (3-6). In immediate replantation, the crucial factors affecting prognosis are the time elapsed between the tooth avulsion and the placement of the tooth, time interval spent in a dry environment and the storage medium. The avulsed teeth should be replanted within the first 15 minutes of the accident so that periodontal ligament cells

\section{Uvod}

Traume zuba čest su zdravstveni problem u dječjoj populaciji (1). Avulzija kao jedna od tih ozljeda definirana je kao potpuno izbijanje zuba iz alveole (2).

Idealan postupak liječenja u slučaju avulzije jest da se zub odmah vrati u alveolu i primijeni tehnika splintiranja, nakon čega se pozorno promatra postoji li revaskularizacija u slučaju nepotpunog razvoja korijena, ili se primjenjuje endodontsko liječenje ako je završen razvoj korijena kako bi se zub sačuvao $(3-6)$. U slučaju imedijatne replantacije ključni čimbenici koji utječu na prognozu su vrijeme proteklo između avulzije i vraćanja zuba te interval proveden u suhom okružju i skladišnom mediju. Avulzirani zub trebalo bi vratiti u alveolu u prvih 15 minuta poslije traume kako bi se sačuvao parodontni ligament koji okružuje površinu korijena (7). Ako je ozljeda stanica parodontnog ligamenta velika, počinje vanjska resorpcija korijena, tvrdo tkivo korijena se ošte- 
surrounding the root surface can be preserved (7). When the periodontal ligament cell injury is large, external root resorption begins, the hard tissue of the root is damaged, and the progression of the damage may lead to tooth loss (8). However, the replantation of avulsed primary teeth is not recommended because of the possible damage to the permanent tooth germ during the procedure, possible infection, and ankylosis $(9,10)$.

If proper first aid procedures are not provided on time due to the lack of knowledge of general dental practitioners (GDPs), many avulsed permanent teeth can be lost, or many permanent successors can be damaged. Therefore, determining the lack of knowledge of GDPs on this issue can be very effective in reducing the poor prognosis of such injuries $(7,11,12)$.

Regarding the trauma knowledge, the knowledge of the GDPs depends on some factors such as their undergraduate education, post-graduate seminars they have received and what they have read about the issue $(12,13)$. The dental education program was reformed under the guidance of the "Profile and Competences for the Graduating European Dentist" and "ADEA Competencies for the New General Dentist" to train dentists under the requirements of the era in Turkey. It is stated that dental students should have the skills of pre-diagnosis, diagnosis and emergency management in avulsion cases (14). Nonetheless, there is limited information about the level of knowledge in emergency management of avulsed teeth for undergraduate students in Turkey $(15,16)$, which is an issue pointing out the aim of this study. The aim of the present study was to evaluate the awareness and knowledge of GDPs for the treatment of traumatic tooth avulsion injuries in Turkey.

\section{Material and Methods}

Ethical approval was received for the study from the Marmara University Faculty of Medicine Non-Interventional Clinical Research Ethics Committee (reference number 06.03.2017-97). The study was then commenced. The participation in the present study was voluntary, and verbal and written informed consents were obtained from all GDPs who were included in the study. In the context of the present study, a questionnaire was completed by GDPs who worked in Istanbul, Turkey.

A confidence interval of $90 \%$ was used for the sample size calculation, with an absolute precision of 0.05 and a power calculation was performed. The analysis suggested that a total sample size of 117 participants was required. In the study, a total of 167 dentists who worked in Istanbul were contacted; $151(90 \%)$ of dentists replied to the questionnaire; and $142(94 \%)$ dentists (female $=85$, male $=57)$ who completed the survey were included in the study. A total of 103, out of 142 dentists, who participated in the present study, completed the questionnaire online.

To measure the knowledge of GDPs on the emergency management of avulsed teeth, a 32-item questionnaire was created by evaluating the studies that were conducted previously on the same topic $(7,11,12,17-19)$. The questionnaire ćuje, a napredovanje oštećenja može završiti gubitkom zuba (8). No ne preporučuje se replantacija mliječnog zuba zbog mogućeg oštećenja trajnog zametka tijekom postupka, infekcije i ankiloze $(9,10)$.

Ako se na vrijeme ne pruži odgovarajuća prva pomoć zbog neznanja liječnika, mnogi avulzirani trajni zubi mogu biti izgubljeni, ili se mogu oštetiti trajni nasljednici. Prema tome, utvrdivanje manjkava znanja općih stomatologa o tom pitanju može biti vrlo učinkovito u smanjenju loše prognoze takvih trauma $(7,11,12)$.

Kad je riječ o informiranosti o traumama, znanje općih stomatologa ovisi o čimbenicima kao što su dodiplomsko obrazovanje, poslijediplomski seminari te informacije koje su pročitali o toj temi $(12,13)$. Program stomatološkog obrazovanja reformiran je u sklopu Profila i kompetencija diplomiranog europskog doktora dentalne medicine i kompetencija ADEA-e o novomu općem stomatologu kako bi se doktori u Turskoj osposobili prema suvremenim zahtjevima. Navodi se da bi studenti dentalne medicine trebali steći vještine za postavljanje preliminarne dijagnoze, konačne dijagnoze i zbrinjavanje hitnih slučajeva nakon avulzije (14). Bez obzira na to, postoji ograničen broj podataka o razini znanja o zbrinjavanju hitnih slučajeva nakon avulzije među studentima preddiplomskoga studija u Turskoj $(15,16)$, što je problem koji upozorava da su potrebna takva istraživanja. Svrha ovog istraživanja bila je procijeniti u Turskoj svijest i znanje općih stomatologa o liječenju traumatskih ozljeda zuba nakon avulzije.

\section{Materijal i metode}

$\mathrm{Za}$ istraživanje je pribavljeno odobrenje Etičkoga povjerenstva za kliničku istraživačku medicinu Sveučilišta Marmara (referentni broj 06.03.2017-97), nakon čega je ono i počelo. Sudjelovanje je bilo dobrovoljno, a usmeni i pisani informirani pristanak dobiven je od svih uključenih općih stomatologa. U sklopu ovog istraživanja upitnik su ispunili opći stomatolozi koji su radili u Istanbulu.

Interval pouzdanosti od $90 \%$ primijenjen je za izračun veličine uzorka s apsolutnom preciznošću od 0,05 . Analiza je pokazala da je potrebna ukupna veličina uzorka od 117 sudionika. U istraživanju se kontaktiralo ukupno sa 167 doktora dentalne medicine koji su radili u Istanbulu - $151(90 \%)$ ispunio je upitnik, a od njih su 142 (94\%) doktora (žena = 85, muškaraca $=57)$ uključena su u istraživanje. Na kraju je 103 liječnika ispunilo anketni upitnik na mreži, od njih 142 koliko ih je sudjelovalo u ovom istraživanju.

Za mjerenje znanja općih stomatologa o hitnom zbrinjavanju avulziranih zuba sastavljen je upitnik s 32 stavke i to poslije procjene istraživanja koja su već provedena o istoj temi $(7,11,12,17$ - 19). U upitniku su postavljena pitanja o tome je li doktor dentalne medicine pohađao tečaj hitnog liječenja dentalnih trauma, je li intervenirao u slučaju avulzije, koje je čimbenike razmatrao pri replantaciji avulziranog zu- 
posed questions about whether GDP's attended a course on emergency treatment of dental traumas, whether they intervened in the treatment of avulsion cases, which factors they considered in the replantation of avulsed teeth, the critical time for the urgent replantation of avulsed teeth, the storage medium and the time of splinting for avulsed teeth.

\section{Statistical Analysis}

The results of the questionnaire were expressed as percentages of frequency distributions. The calculations and statistical analyses of the data obtained were performed using MS-Excel 2010 and SPSS 19.0 for Windows (SPSS Inc., Chicago, IL., USA) package programs with a significance level of 0.05 . The data were analyzed using the chi-square test.

\section{Results}

In the present study, 97 out of the 142 dentists, who participated in the study, were new graduates; 13 had 1-5 years of dental practice experience, and 32 had more than five years of experience. A total of $16(11 \%)$ of these GDPs graduated from private universities, $122(86 \%)$ from state universities and $4(3 \%)$ from foundation universities. $80 \%$ of the GDPs stated that they had received training about avulsion injuries. Figure 1 shows the source of the knowledge of the GDPs on avulsion. Only 40 (28\%) of the GDPs who participated in the present study reported that they had a dental emergency unit in their clinics. Table 1 shows the approaches to GDPs if there is an avulsion case in the area.

When the GDPs were asked whether they would replant an avulsed tooth when a child who lived in their neighborhood had an avulsion, the percentage of the GDPs who would replant such teeth was $56 \%$, and the rest of them answered that they would not replant such teeth. When the GDPs were asked about what to do when the avulsed tooth was dirty, $72(57.5 \%)$ of the GDPs replied that they would rinse the tooth under running water, 21 (17\%) said that they would gently wipe off any mud that was stuck to the tooth, $15(12 \%)$ replied that they would scrub the tooth gently with a toothbrush, $16(13 \%)$ would apply alcohol spray to the avulsed tooth and $1(0.5 \%)$ they would replant the tooth without any pre-treatment.

In the present study, the GDPs were also asked about the factors which influenced the success of the replantation of ba, koje je kritično vrijeme za hitnu replantaciju avulziranog zuba, što zna o medijima za skladištenje avulziranih zuba i o vremenu njihova splintiranja.

\section{Statistička analiza}

Rezultati upitnika izraženi su u postotcima distribucije frekvencija. Izračuni i statističke analize dobivenih podataka provedeni su s pomoću programa MS-Excel 2010 i SPSS 19.0 za Windowse (SPSS Inc., Chicago, IL, SAD) s razinom značajnosti postavljenom na 0,05 . Podatci su analizirani hikvadrat testom.

\section{Rezultati}

U ovom istraživanju tek je diplomiralo 97 od 142 doktora dentalne medicine koji su sudjelovali - 13 je imalo od 1 do 5 godina iskustva u praksi, a 32 više od pet godina. Ukupno $16(11 \%)$ tih doktora diplomiralo je na privatnim sveučlišstima, $122(86 \%)$ na državnim i 4 (3\%) u sveučilišnim ustanovama. Ukupno $80 \%$ doktora izjavilo je da su pohađali predavanja o avulzijama. Slika 1. prikazuje izvor znanja općih stomatologa o avulzijama. Samo 40 (28 \%) liječnika koji su sudjelovali u ovom istraživanju navelo je da u svojim klinikama imaju posebnu jedinicu za hitne slučajeve. Tablica 1. prikazuje pristupe općih stomatologa u slučaju avulzije.

Na pitanje bi li replantirali avulzirani zub kada bi dijete koje živi u njihovu susjedstvu doživjelo takav oblik traume, postotak općih stomatologa koji bi vratili zub bio je $56 \%$, a ostali su odgovorili da to ne bi učinili. Na pitanje što učiniti ako je avulzirani zub zaprljan, 72 (57,5\%) doktora odgovorila su da bi ga isprali tekućom vodom, 21 (17 \%) da bi ga nježno obrisali kako bi uklonili prljavštinu sa zuba, 15 (12 $\%)$ bi ga očistilo četkicom za zube, $16(13 \%)$ bi nanijelo alkoholni sprej na avulzirani zub, a $1(0,5 \%)$ bi zub vratio bez ikakve pripreme.

$\mathrm{U}$ ovom istraživanju doktori dentalne medicine također su ispitivani o čimbenicima koji utječu na uspješnost replantacije zuba. Distribucija odgovora nalazi se u tablici 2. Gotovo su svi $(99,3 \%)$ izjavili da bi avulzirani zub držali za krunu. Ukupno njih 113 (80 \%) odgovorilo je da bi pažljivo isprali alveolu avulziranog zuba fiziološkom otopinom $\mathrm{i}$ aspirira-

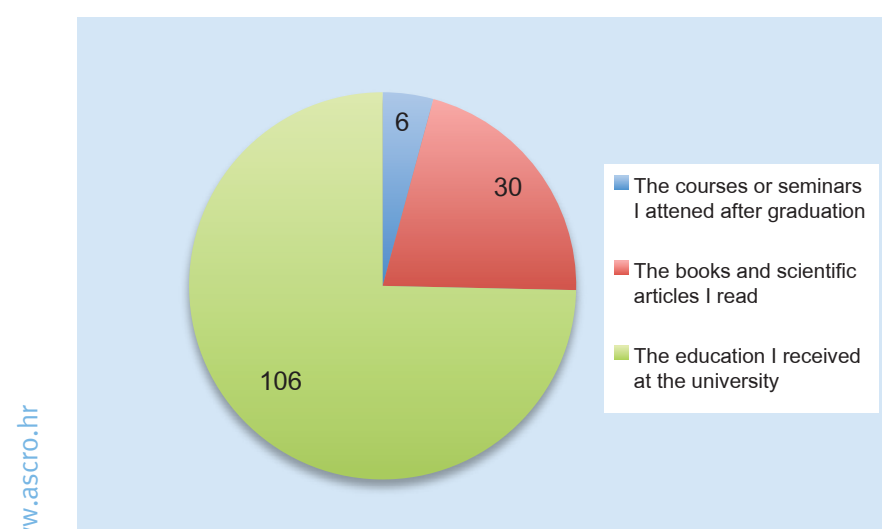

Figure 1 The source of the knowledge of the dentists on avulsion Slika 1. Izvori znanja doktora dentalne medicine o avulzijama 
Table 1 The approaches of dentists to an avulsion case

Tablica 1. Pristupi doktora dentalne medicine u slučaju avulzije zuba

\begin{tabular}{|c|c|}
\hline $\begin{array}{l}\text { If you were at a site where someone had avulsed a tooth, would you? } \\
\text { Da ste u blizini kada se dogodila avulzija zuba, što biste učinili? }\end{array}$ & $\begin{array}{c}\text { Dentists } \\
\text { Doktori dentalne medicine } \\
(\%)\end{array}$ \\
\hline Be confident and replant the tooth $\bullet$ Bili biste suvereni i replantirali zub & $61(43 \%)$ \\
\hline Not be confident but you would replant the tooth anyway $\bullet$ Ne biste bili sigurni, ali bi svejedno nešto poduzeli & $57(40 \%)$ \\
\hline Not take action because you lack knowledge and training $\bullet$ Ne biste poduzeli ništa zbog manjka znanja i iskustva & $17(12 \%)$ \\
\hline Not take action because of the medico-legal consequences $\bullet$ Ne biste poduzeli ništa zbog medicinsko-pravnih posljedica & $7(5 \%)$ \\
\hline
\end{tabular}

Table 2 Which is the most critical factor that may influence the outcome of replantation?

Tablica 2. Koji je najkritičniji čimbenik koji može utjecati na ishod replantacije?

\begin{tabular}{|c|c|}
\hline $\begin{array}{l}\text { The factors on which the treatment success of avulsed teeth depends } \\
\text { Čimbenici o kojima ovisi uspjeh liječenja avulziranih zuba }\end{array}$ & $\begin{array}{c}\text { Dentists } \bullet \\
\text { Doktori dentalne medicine } \\
(\%)\end{array}$ \\
\hline The damage of periodontal ligament cells $\bullet$ Oštećenje stanica parodontnog ligamenta & $0(0 \%)$ \\
\hline The storage conditions of avulsed teeth $\bullet$ Uvjeti pohranjivanja avulziranog zuba & $2(1 \%)$ \\
\hline The time that passes after the trauma $\bullet$ Vrijeme proteklo od traume & $4(3 \%)$ \\
\hline All $\bullet$ Sve & $136(96 \%)$ \\
\hline
\end{tabular}

avulsed teeth. The distribution of the answers is shown in Table 2. Almost all (99.3\%) of the GDPs stated that they would hold the avulsed tooth by the crown, and $0.7 \%$ of the GDPs stated that they did not notice the region of the tooth. A total of $113(80 \%)$ of the GDPs who participated in the present study stated that they would carefully irrigate and aspirate it with physiological saline the blood clot in the tooth socket of an avulsed tooth; 20 (14\%) stated that they would not remove the clot, $6(4 \%)$ stated that they would remove the clot with curettage and $3(2 \%)$ marked the "other" option.

The questions and their answers to the questions on the emergency management on avulsed teeth in the questionnaire are shown in Table 3. The correct responses of GDPs were statistically higher regarding the replantation of primary teeth $(92 \%)$, optimal storage medium for avulsed teeth $(78 \%)(p=0.000, p=0.000)$. On the other hand, GDPs who responded incorrectly about the critical time for the treatment of avulsed teeth $(65 \%)$ were statistically more numerous $(\mathrm{p}=0.000)$. There was no statistical difference in responses regarding systemic medications after avulsion $(\mathrm{p}=0.332)$. The answers were analyzed according to the GDPs' experience, additional education, and the source of their knowledge (Table 4 and Table 5).

When the GDPs were asked about how the open or closed apices would affect the prognosis of the treatment in avulsed teeth, $10(7 \%)$ of them stated that the prognosis would not be changed. A total of 111 (78\%) of these GDPs stated that the apex of open (immature) teeth had a better prognosis, and $31(22 \%)$ stated that the apex of the closed (mature) teeth had a better prognosis.

Finally, the participating GDPs were asked about the aspiration of avulsed teeth in the questionnaire. A total of 64 (45\%) of them stated that lung radiography should be carried out, $28(19.7 \%)$ stated that bronchoscopy should be carried out, $29(20.4 \%)$ chose to make the patient vomit, 12 (8.4\%) stated that lung control should be carried out with a stethoscope and $53(37 \%)$ stated that they had no idea. li krvni ugrušak, 20 (14\%) je izjavilo da ne bi uklonili ugrušak, 6 (4\%) bi ugrušak uklonilo kiretiranjem, a $3(2 \%)$ su zaokružili odgovor ostalo.

Pitanja i odgovori o hitnom zbrinjavanju avulziranih zuba u upitniku prikazani su u tablici 3. Točni odgovori doktora bili su statistički češći kad je riječ o replantaciji mliječnih zubi (92 \%) i optimalnom sredstvu za pohranjivanje avulziranog zuba $(78 \%)(p=0,000, p=0,000) . S$ druge strane, doktori koji su pogrešno odgovorili na pitanje o kritičnom vremenu za liječenje avulziranih zuba $(65 \%)$ bili su statistički značajno brojniji $(p=0,000)$. Nije bilo statističke razlike u odgovorima o sistemskoj primjeni lijekova nakon avulzije $(\mathrm{p}=0,332)$. Odgovori su analizirani prema iskustvu doktora dentalne medicine, dodatnom obrazovanju i izvoru njihova znanja (tablica 4. i tablica 5.).

Na pitanje kako će otvoreni ili zatvoreni apeks utjecati na prognozu liječenja avulziranih zuba, $10(7 \%)$ doktora izjavilo je da se prognoza neće mijenjati. Ukupno 111 (78 \%) ispitanika odgovorilo je da apeks otvorenih (nezrelih) zuba ima bolju prognozu, a $31(22 \%)$ smatra da apeks zatvorenih (zrelih) zuba ima bolju prognozu.

$\mathrm{Na}$ kraju su postavljena pitanja o aspiraciji avulziranih zuba. Ukupno 64 (45\%) ispitanika izjasnila su se da treba rendgenski snimiti pluća, $28(19,7 \%)$ izjavilo je da se mora obaviti bronhoskopija, $29(20,4 \%)$ bi pacijenta natjeralo na povraćanje, $12(8,4 \%)$ je smatralo da se pluća trebaju provjeriti stetoskopom, a $53(37 \%)$ je izjavilo da nemaju pojma. 
Table 3 The knowledge of emergency treatment of avulsed teeth

Tablica 3. Znanje o hitnom zbrinjavanju avulziranog zuba

\section{Knowledge $\bullet$ Znanje}

\section{GDPs •}

Doktor dentalne medicine

\section{Replantation of primary teeth $\bullet$ Replantacija mliječnog zuba}

Yes $\bullet$ Da

$\mathrm{No} \cdot \mathrm{Ne}$

2. Critical time for treatment $\bullet$ Kritično vrijeme za liječenje

Within $30 \mathrm{~min} \bullet$ unutar $30 \mathrm{~min}$.

30-60 min

Within $2 \mathrm{~h} \cdot$ unutar 2 sata

Not sure $\bullet$ Nisam siguran

3. Optimal storage medium $\bullet$ Optimalan medij za pohranjivanje

Milk $\bullet$ Mlijeko

Patient's mouth (Saliva) $\bullet$ Pacijentova usta (slina)

Physiologic saline solution $\bullet$ Fiziološka otopina

Contact lens solution $\bullet$ Otopina za leće

Tap water $\bullet$ Voda iz slavine

Warm water $\bullet$ Topla voda

Cold water $\bullet$ Hladna voda

Wrap it with gauze $\bullet$ Umotavanje u gazu

Disinfectant solution $\bullet$ Dezinfekcijska otopina

Water with a pinch of salt $\bullet$ Voda s prstohvatom soli

Ice $\bullet$ Led

No need to store the tooth - Ne treba pohranjivati zub

\section{Type of splint $\bullet$ Vrsta splinta}

Flexible splint $\bullet$ Fleksibilni splint

Rigid splint $\bullet$ Rigidni splint

Does not matter $\bullet$ Ne igra ulogu

Not sure $\bullet$ Nisam siguran

\section{Splinting period $\bullet$ Trajanje splintiranja}

2 weeks $\bullet 2$ tjedna

4 weeks $\bullet 4$ tjedna

6 weeks $\bullet 6$ tjedana

Not sure $\bullet$ Nisam siguran

6. Intra-canal medication used for root canal treatment • Intrakanalni uložak

Calcium hydroxide paste $\bullet$ Pasta kalcijeva hidroksida

Zinc oxide paste $\bullet$ Cinkova oksidna pasta

Not sure $\bullet$ Nisam siguran

\section{Systemic medication $\bullet$ Sistemska medikacija}

Antib. ${ }^{\dagger}$, anti-inf. ${ }^{\ddagger}$, tetanus vaccine $\bullet$ Antib. ${ }^{\dagger}$, antiinf. ${ }^{\ddagger}$, cjepivo protiv tetanusa Anti-inf.

Antib.

Antib. and tetanus vaccine $\bullet$ Antib. i cjepivo protiv tetanusa

Antib. and anti-inf. $\bullet$ Antib. i antiinf.

Tetanus vaccine $\bullet$ Cjepivo protiv tetanusa

Tetanus vaccine and anti-inf. $\bullet$ Cjepivo protiv tetanusa i antiinf.

Others $\bullet$ Ostalo

${ }^{*} \mathrm{p}<0.05 \dagger$ Antib.: Antibiotics $\bullet$ antibiotici, $\ddagger$ Anti-inf.: Anti-inflammatory drugs $\bullet$ protuupalni lijekovi

\begin{tabular}{|c|c|}
\hline 49 & $35 \%$ \\
\hline 60 & $42 \%$ \\
\hline 22 & $15 \%$ \\
\hline 11 & $8 \%$ \\
\hline
\end{tabular}

\begin{tabular}{c|c|}
140 & $27 \%$ \\
\hline 113 & $22 \%$ \\
\hline 108 & $21 \%$ \\
\hline 42 & $8 \%$ \\
\hline 27 & $5 \%$ \\
\hline 16 & $5 \%$ \\
\hline 14 & $3 \%$ \\
\hline 13 & $3 \%$ \\
9 & $3 \%$ \\
4 & $2 \%$ \\
\hline 0 & $1 \%$ \\
\hline
\end{tabular}

\begin{tabular}{c|c}
80 & $56 \%$ \\
\hline 41 & $29 \%$ \\
\hline 2 & $1.5 \%$ \\
\hline 19 & $13.5 \%$
\end{tabular}

\begin{tabular}{c|c}
83 & $58.5 \%$ \\
\hline 34 & $24 \%$ \\
\hline 2 & $1.5 \%$ \\
\hline 23 & $16 \%$ \\
\hline
\end{tabular}

\begin{tabular}{c|c}
\hline 123 & $86.5 \%$ \\
\hline 7 & $5 \%$ \\
\hline 12 & $8.5 \%$
\end{tabular}

$32 \%$

\begin{tabular}{l|l}
46 & $32 \%$ \\
\hline 17 & $12 \%$
\end{tabular}

\begin{tabular}{|c|c|}
\hline 17 & $32 \%$ \\
\hline 37 & $12 \%$ \\
\hline 20 & $14 \%$ \\
\hline 10 & $7 \%$ \\
\hline 7 & $5 \%$ \\
\hline 4 & $3 \%$ \\
\hline 1 & $0.7 \%$ \\
\hline
\end{tabular}


Table 4. The answers according to the GDPs' experience, additional education, and the source of their knowledge Tablica 4. Odgovori s obzirom na iskustvo, dodatnu edukaciju i izvor znanja

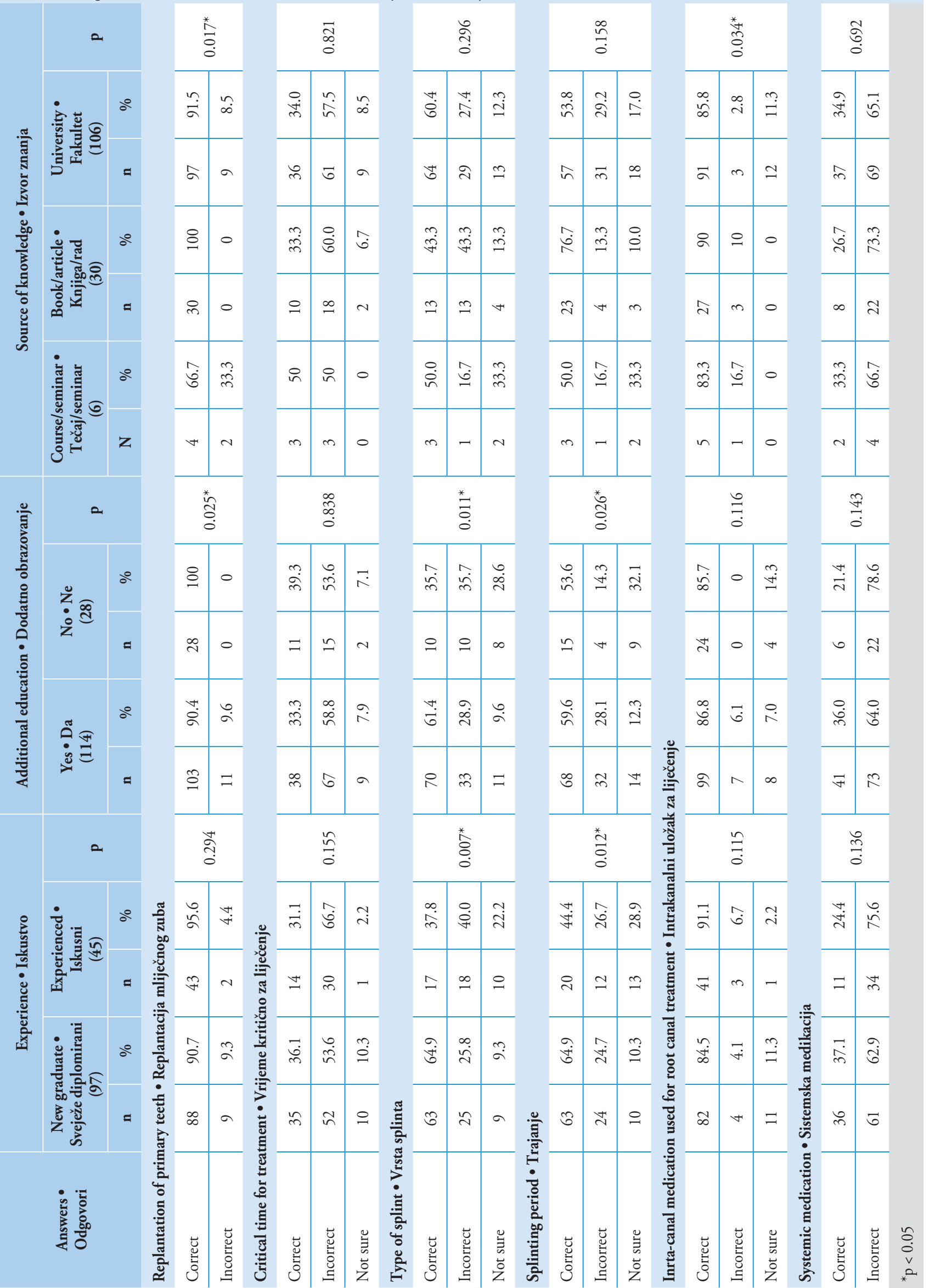


Table 5. The knowledge of optimal storage solution

Tablica 5. Poznavanje optimalne otopine za pohranjivanje zuba

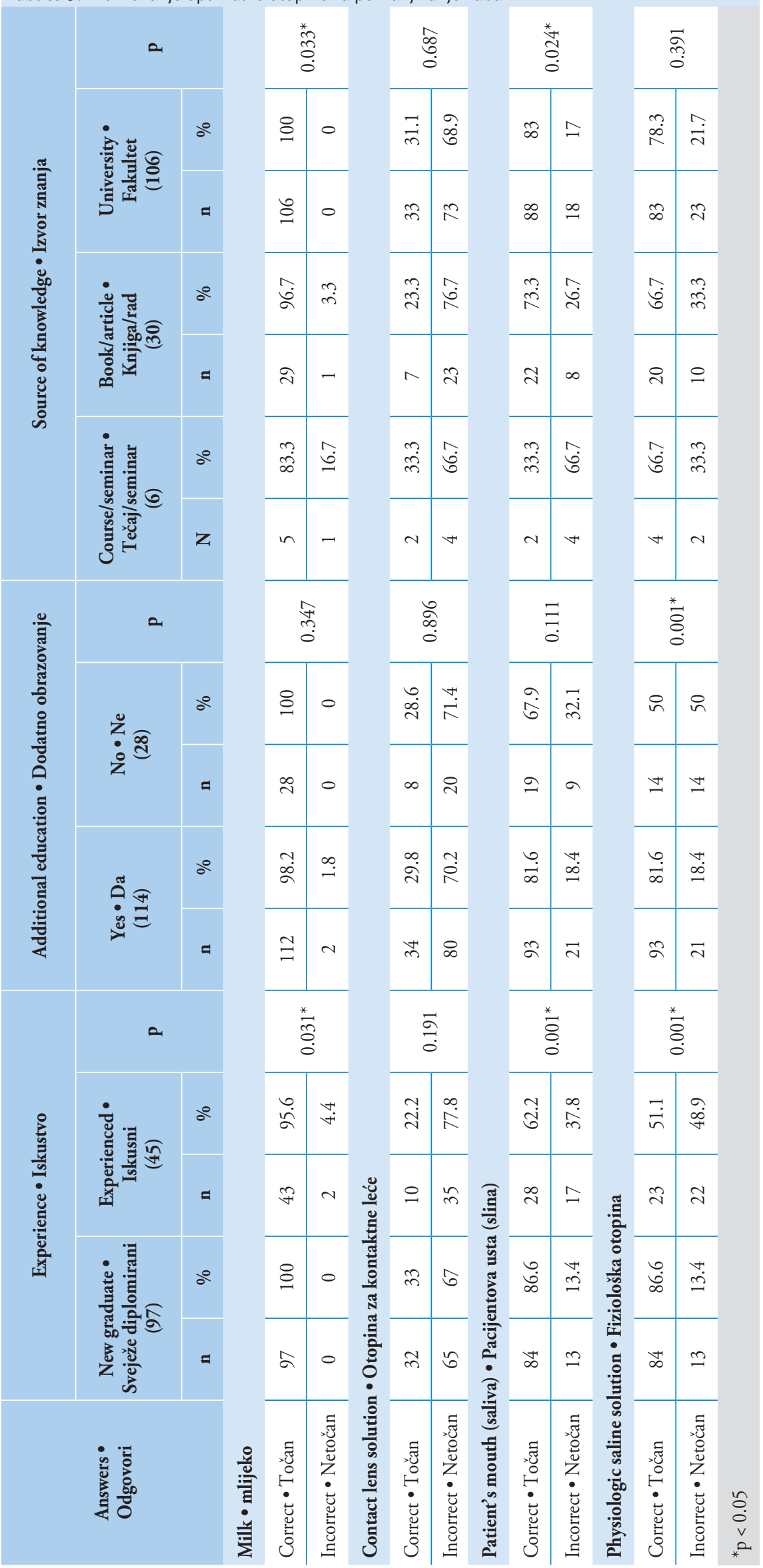




\section{Discussion}

In the present survey, the participating GDPs were from private, state or foundation universities in Istanbul, Turkey. The dentists who participated in the study did not have any dental expertise. A questionnaire on emergency management after dental avulsion was given to GDPs, who had various levels of experience. The questionnaire included 32 questions and was prepared by examining similar studies in the literature $(7,11,12,17-19)$.

Although the knowledge levels of most of the GDPs on the critical treatment period after an avulsion, avulsion of primary teeth, and the storage medium of the teeth were correct, their level of knowledge on intra-canal medication and splinting techniques need to be higher for clinical success. In the present study, more than half of GDPs told that the ideal splint type was a flexible splint. This rate was reported as much higher than the study of Vasconcellos et al. (20). Besides, $58 \%$ of the GDPs are recorded as correct in this study, which is more than the study by Cinar et al. (21).

A study published in Turkey in 2020, showed that the knowledge level of more experienced dentists was lower (16). Similarly, in this study, more new graduates knew the answers to most of the questions. Also, there was a statistical difference in responses regarding the type of splint, splinting period, and optimal storage medium since GDPs may have forgotten to update their knowledge. Unlike these studies, Kariya et al. (10) stated that the experience of GDPs increased the level of knowledge regarding the critical time for treatment of avulsed teeth.

Al-Zubair (12) conducted a study in 2015 and found that approximately half of the dentists in Yemen (46\%) received their knowledge on the avulsion treatment of dental avulsion from the books and scientific articles they had read. Kenny et al. (22) reported that $40 \%$ of the dentists in Yorkshire received postgraduate training in dental trauma. In this respect, most dentists who participated in the current study, $75 \%$ of them, stated that the source of their knowledge on the treatment of avulsion was the university education they received. In a study that was conducted by Zhao and Gong (17) in China, a total of 56\% of the dentists stated that they did not receive any education on this topic at the university. The study of Upadhyay et al. (18) reported that $93 \%$ of the dentists in Nepal did not receive any training. In the current study, GDPs who received additional education, were familiar with the splint type, the splinting period, and milk for storage solutions in a statistically better manner. But GDPs who did not receive additional education knew that the avulsed primary tooth should not be replanted. It was determined that $80 \%$ of the GDPs in Istanbul received training in this field at the University. The impact of the knowledge source differed depending on the questions.

In the studies conducted in two different regions of $\mathrm{Ne}$ pal, the dentists were asked the following question: "Should the avulsed teeth be replanted?" to which $86 \%$, and $31 \%$ of the participating dentists replied: "No" $(11,18)$. In similar studies conducted in China and Saudi Arabia, the rates of the "No" answer were $87 \%$ and $85 \%$ respectively $(17,23)$,

\section{Rasprava}

Doktori dentalne medicine koji su sudjelovali u ovom istraživanju bili su iz privatnih, državnih ili sveučilišnih klinika u Istanbulu. Upitnik o zbrinjavanju hitnih slučajeva nakon zubne avulzije ispunjavali su liječnici s različitim razinama iskustva. Upitnik je sadržavao 32 pitanja, a pripremljen je prema uzorku za slična istraživanja $(7,11,12,17$ - 19).

Iako su razine znanja većine doktora dentalne medicine o kritičnom razdoblju liječenja nakon avulzije, avulziji mliječnih zuba i sredstvima za pohranjivanje avulziranog zuba bile točne, za klinički uspjeh trebala bi biti veća razina njihova znanja o intrakanalnim lijekovima i tehnikama splintiranja. $\mathrm{U}$ ovom istraživanju više od polovine doktora reklo je da je idealan tip splinta fleksibilan. Ta stopa bila je mnogo veća negoli u istraživanju Vasconcellosa i suradnika (20). Osim toga, u ovom je istraživanju $58 \%$ odgovora bilo točno, što je više negoli u istraživanju Cinara i suradnika (21).

Studija objavljena u Turskoj 2020. pokazala je da je razina znanja iskusnijih doktora niža (16). Slično tomu, u ovom je istraživanju više novih diplomanata znalo odgovore na većinu pitanja. Zabilježena je također statistički značajna razlika u odgovorima koji se odnose na vrstu splinta, trajanje splintiranja i optimalni medij za pohranjivanje zuba, jer su doktori možda zaboravili obnoviti svoje znanje. Za razliku od ovih istraživanja, Kariya i suradnici (10) naveli su da je iskustvo doktora povećavalo razinu znanja o kritičnom vremenu liječenja avulziranih zuba.

Al-Zubair (12) proveo je istraživanje 2015. i ustanovio da je otprilike polovina doktora dentalne medicine u Jemenu (46\%) svoje znanje o liječenju avulziranoh zuba stekla iz knjiga i znanstvenih članaka. Kenny i suradnici (22) izvijestili su da je $40 \%$ doktora dentalne medicine u Yorkshireu završilo postdiplomsku izobrazbu o dentalnim traumama. U tom kontekstu, većina ispitanika koji su sudjelovali u ovom istraživanju - njih $75 \%$, navela je da je izvor njihova znanja o liječenju avulzija fakultetsko obrazovanje koje su stekli. U istraživanju koje su u Kini proveli Zhao i Gong (17), ukupno $56 \%$ doktora dentalne medicine izjavilo je da na fakultetu nisu ništa naučili o toj temi. U istraživanju Upadhyaya i suradnika (18) navodi se da $93 \%$ doktora dentalne medicine u Nepalu nije sudjelovalo ni u kakvoj dodatnoj izobrazbi. U ovom istraživanju su doktori koji su se dodatno educirali bili statistički značajno bolje obaviješteni o vrstama splintova, razdoblju splintiranja i mlijeku kao rješenju za pohranjivanje. Ali doktori koji se nisu dodatno educirali znali su da avulzirane mliječne zube ne treba replantirati. Utvrđeno je da je 80 $\%$ općih stomatologa u Istanbulu imalo poduku iz toga područja na sveučilištu. Utjecaj izvora znanja razlikovao se ovisno o pitanjima.

$\mathrm{U}$ istraživanjima koja su provedena $\mathrm{u}$ dvjema različitim pokrajinama Nepala, doktorima je postavljeno sljedeće pitanje: Treba li avuzirane zube replantirati?, na što je $86 \%$ i 31 $\%$ stomatologa koji su sudjelovali odgovorilo negativno (11, 18). U sličnim istraživanjima provedenima u Kini i Saudijskoj Arabiji stope negativnih odgovora bile su $87 \%$, odnosno $85 \%(17,23)$, a u ovom istraživanju njih $92 \%$ odgovorilo je negativno. Holan i Shmueli (19) pokazali su 2003. 
whereas in the present study, 92\% answered "No". Holan and Shmueli (19) in 2003, reported that 50\% of the dentists in Israel told that avulsed permanent teeth should not be replanted, and $8 \%$ said that they had no idea. In the present study; however, no dentists selected the option that such teeth should not be replanted and only $0.7 \%$ stated that they did not have any idea.

Similar to the current study, Al-Zubair (12) conducted a study in Yemen and asked the dentists about the necessary factors for the success of the replantation of avulsed teeth. A total of $53 \%$ of dentists stated that all the factors including the time elapsed after the trauma, the storage conditions of avulsed teeth, and the periodontal ligament damage affect the success, while $47 \%$ selected only one factor among the three abovementioned factors. In the present study, on the other hand, $96 \%$ of the dentists stated that all the factors influence a successful outcome.

The responses of dentists in several studies on the storage conditions of avulsed teeth stated that the most suitable storage condition was saliva $(11,12,17)$. However, Abu-Dawoud et al. (7) and Al-Haj Ali et al. (23) reported that dentists stated that milk was the best storage medium for avulsed teeth. In the study by Upadhyay et al. (18), $59.8 \%$ of the participating dentists stated that Hank's balanced salt solution was the ideal storage medium. Fujita et al. (24) reported that sixthyear dental students in Japan were familiar with the fact that milk and physiological saline solution were the most practical transport media for the storage of avulsed teeth because their $\mathrm{pH}$ and osmolality were similar to those of extracellular fluid.

In the present study, the GDPs stated that they would prefer calcium hydroxide as an intra-canal medicament for root canal treatment of avulsed teeth, at a higher rate than other studies $(17,18)$. The reason why calcium hydroxide is by far the most widely used intra-canal medication is due to its inhibition of bacterial enzymes, producing an antimicrobial effect, which activates some tissue enzymes, producing a mineralizing effect (25).

When the responses of the GDPs in the current study were examined, it was determined that many participants did not attend any courses or seminars on the emergency management of avulsed teeth; and most of them did not treat the patients with avulsed teeth due to dental trauma. Nevertheless, when the responses to the questions regarding the knowledge of the treatment of avulsed teeth were evaluated, it was observed that the response to the emergency knowledge of the participating GDPs was close to the rates reported in previous studies in the literature. Some responses were even better. However, in the present study, it was emphasized that the knowledge of the GDPs about this topic needs to be improved.

\section{Conclusion}

In the present study, the following conclusions can be drawn: The overall knowledge of GDPs about the emergency management of avulsed teeth was found to be moderate. However, the answers of most GDPs were correct regarding the replantation of primary teeth; The fact that experienced GDPs had less information points to the importance of up- da je $50 \%$ stomatologa u Izraelu navelo da se avulzirani trajni zubi ne smiju replantirati, a $8 \%$ reklo je da nema pojma. $\mathrm{U}$ ovoj studiji nijedan ispitanik nije odabrao opciju da se takvi zubi ne trebaju vratiti u alveolu, a samo $0,7 \%$ izjavilo je da nema pojma.

Slično kao u ovom istraživanju, Al-Zubair (12) proveo je istraživanje u Jemenu i pitao doktore dentalne medicine o potrebnim čimbenicima za uspjeh replantacije avulziranih zuba. Ukupno $53 \%$ ispitanika izjavilo je da svi čimbenici, uključujući vrijeme proteklo od traume, uvjete pohranjivanja avulziranog zuba i oštećenje parodontnog ligamenta, utječu na uspjeh, a $47 \%$ odabralo je samo jedan čimbenik između triju gore navedenih. Istodobno, u ovom je istraživanju $96 \%$ ispitanika izjavilo da svi čimbenici utječu na uspješan ishod.

U nekoliko istraživanja o uvjetima pohranjivanja avulziranih zuba doktori dentalne medicine naveli su da je najprikladnija slina $(11,12,17)$. No Abu-Dawoud i suradnici (7) te Al-Haj Ali i suradnici (23) izvijestili su da su doktori dentalne medicine smatrali da je mlijeko najbolji medij za pohranjivanje avulziranih zuba. U istraživanju Upadhyaya i suradnika (18) 59,8 \% doktora koji su sudjelovali izjavilo je da je Hankova izbalansirana slana otopina idealan medij za pohranjivanje. Fujita i suradnici (24) istaknuli su da studenti šeste godine dentalne medicine u Japanu znaju da su mlijeko i fiziološka otopina najpraktičniji transportni medij za pohranjivanje avulziranih zuba jer su njihov pH i osmolalnost slični onima u izvanstaničnoj tekućini.

$\mathrm{U}$ ovom istraživanju ispitanici su izjavili da prednost daju kalcijevu hidroksidu kao intrakanalnom ulošku za liječenje korijenskih kanala avulziranih zuba, više negoli u drugim istraživanjima $(17,18)$. Razlog da je kalcijev hidroksid najčešće korišten intrakanalni lijek jest inhibicija bakterijskih enzima koji stvaraju antimikrobni učinak, a on pak aktivira neke tkivne enzime potičući mineralizaciju (25).

Kad su analizirani odgovori doktora dentalne medicine $\mathrm{u}$ ovom istraživanju, utvrđeno je da mnogi nisu pohađali nikakve tečajeve ili seminare o hitnom zbrinjavanju avulziranih zuba, a većina nije niti liječila pacijente $s$ avulzijama nakon dentalne traume. Ipak, kad su analizirani odgovori na pitanja koja se odnose na znanje o liječenju avulziranih zuba, uočeno je da su odgovori vezani za znanje o hitnom zbrinjavanju bili slični onima iz prethodnih istraživanja. Neki su odgovori bili još bolji. No u ovom je istraživanju istaknuto da je potrebno poboljšati znanje općih stomatologa o toj temi.

\section{Zaključak}

U ovom istraživanju zaključci su sljedeći: Otkriveno je da je sveukupno znanje općih stomatologa o hitnom zbrinjavanju avulziranih zuba umjereno. No odgovori većine ispitanika u vezi s replantacijom mliječnih zuba bili su točni; Činjenica da su iskusni doktori imali manje informacija upućuje na važnost obnavljanja znanja; Manjkavost istraživanja jest u 
dating the information; One limitation of the study was that its results are limited to restricted sample size. The larger sample size would be a better measure to dentify the results; It is concluded that as GDPs form a vital link to the patient, hence, they need to be educated on the emergency management of avulsed teeth by providing postgraduate continuing education programs to improve their awareness and knowledge. The correct management of the avulsion case by GDP will result in an increased success of the treatment. Furthermore, the awareness of GDPs should be raised to the availability of the IADT guideline with online tools such as the IADT website (www.iadt-dentaltrauma.org/) and phone application (Tooth SOS, Official App of IADT).

\section{Source of Funding}

The authors declared that this study has received no financial support.

\section{Conflict of Interest}

The authors have no conflicts of interest to declare. tome da su njegovi rezultati dobiveni na ograničenoj veličini uzorka - veći uzorak omogućio bi pouzdanije rezultate; Zaključeno je da su opći stomatolozi ključna spona prema pacijentu i zato ih je potrebno educirati o hitnom zbrinjavanju avulziranih zuba u sklopu programa kontinuiranog obrazovanja radi poboljšanja njihove svijesti i znanja. Pravilno zbrinjavanje avlzija rezultirat će povećanim uspjehom u liječenju. Nadalje, trebala bi se podignuti svijest doktora o dostupnosti smjernica IADT-a s mrežnim alatima (www.iadt-dentaltrauma.org/) i telefonskim aplikacijama (Tooth SOS, službena aplikacija IADT-a).

\section{Izvor financiranja}

Autori su izjavili da za istraživanje nisu dobili financijsku potporu.

\section{Sukob interesa}

Autori su izjavili da nisu bili u sukobu interesa.

\section{Sažetak}

Svrha rada: Željelo se istražiti znanje i stajalište općih stomatologa o hitnom liječenju avulziranih zuba. Naime, malo je podataka o razini znanja o zbrinjavanju avulzija među mladim doktorima dentalne medicine u Turskoj. Materijali i metode: Pripremljen je presječni upitnik kako bi se procijenilo znanje općih stomatologa o hitnom zbrinjavanju avulziranih zuba. Ispunila su ga 42 doktora dentalne medicine, a pitanja su bila o tome jesu li dobili informacije o hitnom liječenju zubnih trauma, jesu li intervenirali u slučaju avulziranog zuba nakon traume i jesu li liječili avulzirane zube. Rezultati: Većina općih stomatologa pohađala je predavanja o liječenju avulzija zuba. Rezultati istraživanja pokazali su da se samo njih $35 \%$ prisjetilo kritičnog vremena liječenja. Broj onih koji su imali pogrešna znanja o toj temi bio je veći i statistički značajan $(p<0,001)$. Stope točnih odgovora prema relevantnim informacijskim poljima bile su sljedeće: optimalni medij za pohranu ( $78 \%$ ), vrsta splinta (56\%), razdoblje splintiranja (58,5 \%) i sistemski lijekovi nakon avulzije (32\%). Zaključak: Rezultati pokazuju da je mnogo općih stomatologa steklo ograničeno iskustvo u liječenju avulziranih zuba. No u istraživanju je istaknuto da bi se znanje, u vezi s čimbenicima koji utječu na uspješno liječenje avulzije, trebalo poboljšati programima kontinuiranog obrazovanja.
Zaprimljen: 29. siječnja 2020 Prihvaćen: 9. svibnja 2020.

Adresa za dopisivanje

Betul Sen-Yavuz

ORCID: 0000-0002-7561-8396

Bahcesehir University, School of

Dental Medicine,

Department of Pediatric Dentistry

Istanbul, Turkey.

tel: +90 5399887646

dtbetulsen@gmail.com

Ključne riječi

traume zuba; izbijanje zuba; hitni postupci; replantacija zuba; zdravstvene spoznaje stavovi i praksa; klinički obrasci u stomatologiji

\section{References}

1. Toprak ME, Tuna EB, Seymen F, Gençay KA. Traumatic dental injuries in Turkish children, Istanbul. Dent Traumatol. 2014 Aug;30(4):280-4.

2. Ferres-Amat E, Diaz-Martinez C, Herrera-Martinez S, Maura-Solivellas I, Ferres-Padro E. Unusual transalveolar and transmuco-gingival root avulsion of a fractured primary central incisor: a case with an 8-year follow-up. Case Rep Dent. 2015;2015:914846.

3. Andersson L, Adreasen JO, Day P, Heithersay G, Trope M, Daingelis AJ, et al. International association of dental traumatology guidelines for the management of traumatic dental injuries: 2 . avulsion of permanent teeth. Dent Traumatol. 2012 Apr;28(2):88-96.

4. Panzarini SR, Trevisan CL, Brandini DA, Poi WR, Sonoda CK, Luvizuto ER, et al. Intracanal dressing and root canal filling materials in tooth replantation: a literature review. Dent Traumatol. 2012 Feb;28(1):42-8.

5. Trope M, Moshonov J, Nissan R, Buxt P, Yesilsoy C. Short vs. Longterm calcium hydroxide treatment of established inflammatory root resorption in replanted dog teeth. Endod Dent Traumatol. 1995 Jun;11(3):124-8.

6. Dominguez Reyes A, Muñoz Muñoz L, Aznar Martín T. Study of calcium hydroxide apexification in 26 young permanent incisors. Dent Traumatol. 2005 Jun;21(3):141-5.

7. Abu-Dawoud M, Al-Enezi B, Andersson L. Knowledge of emergency management of avulsed teeth among young physicians and dentists. Dent Traumatol. 2007 Dec;23(6):348-55.
8. Lima TFR, Silva EJNLD, Gomes BPFA, Almeida JFA, Zaia AA, Soares AJ. Relationship between initial attendance after dental trauma and development of external inflammatory root resorption. Braz Dent J. 2017;28(2):201-5.

9. Firedlander LT, Chandler NP, Drummond BK. Avulsion and replantation of a primary incisor tooth. Dent Traumatol. 2013 Dec;29(6):494-7.

10. Kariya PB, Singh S, Bargale S, Shah S, Kulkarni N, Dave BH. Evaluation of knowledge regarding emergency management of avulsed traumatic dental injuries in children among general dental practitioners in India. Indian J Dent Res. 2019;30(1):21-6.

11. Limbu S, Dikshit P, Bhagat T, Mehata S. Knowledge of dental interns towards emergency management of avulsed tooth in dental colleges in Nepal. J Nepal Health Res Counc. 2014 Jan;12(26):1-7.

12. Al-Zubair NM. General dentists' knowledge about the emergency management of dental avulsion in Yemen. $S \mathrm{~J}$ Oral Sci. 2015;2(1):25-9.

13. Karapinar- Kazandag M, Tanalp J, Ayhan T, Kaptan RF, Ersev H. Evaluation of retention of dental students' trauma knowledge following a reminder lecture. Biomed Res. 2018;29(9):1756-63.

14. MeSH Browser[database on the Internet]. Diş Hekimliği Dekanları Konseyi. Mezuniyet Öncesi Diş Hekimliği Eğitimi Ulusal Çekirdek Eğitim Programı. 2016. Available online: http://ddk.org.tr/wp-content/uploads/2018/03/ddk2016ducep2016.pdf. (accessed on 4 April 2020). 
15. Buldur B, Kapdan A. Factors associated with knowledge and attitude of management of traumatic dental injuries: a cross-sectional study among Turkish dentists. Pesq bras odontoped Clin Integr. 2018;18(1):e3948.

16. Duruk G, Erel ZB. Assessment of Turkish dentists' knowledge about managing avulsed teeth. Dent Traumatol. 2020 Jan 10.

17. Zhao Y, Gong Y. Knowledge of emergency management of avulsed teeth: a survey of dentists in Beijing, China. Dent Traumatol. 2010 Jun;26(3):281-4.

18. Upadhyay S, Rokaya D, Upadhyaya C. Knowledge of emergency management of avulsed teeth among general dentists in Kathmandu. Kathmandu Univ Med J (KUMJ). 2012 Apr-Jun;10(38):37-40.

19. Holan G, Shmueli Y. Knowledge of physicians in hospital emergency rooms in Israel on their role in cases of avulsion of permanent incisors. Int J Paediatr Dent. 2003 Jan;13(1):13-9.

20. De Vasconcellos LG, Brentel AS, Vanderlei AD, De Vasconcellos LM, Valera MC, De Araujo MA. Knowledge of general dentists in the current guidelines for emergency treatment of avulsed teeth and dental trauma prevention. Dent Traumatol. 2009 Dec;25(6):578-83.

21. Cinar C, Atabek D, Alacam A. Knowledge of dentists in the management of traumatic dental injuries in Ankara, Turkey. Oral Health Prev Dent. 2013;11(1):23-30.

22. Kenny KP, Day PF, Douglas GVA, Chadwick BL. Primary care dentists' experience of treating avulsed permanent teeth. Br Dent J. 2015 Sep 11;219(5): E4.

23. Al-Haj Ali SN, Algarawi SA, Alrubaian AM, Alasgah Al. Knowledge of general dental practitioners and specialists about emergency management of traumatic dental injuries in Qassim, Saudi Arabia. Int J Pediatr. 2020 Feb 19;2020:6059346.

24. Fujita Y, Shiono Y, Maki K. Knowledge of emergency management of avulsed tooth among Japanese dental students. BMC Oral Health. 2014 Apr 8;14:34.

25. Panzarini SR, Trevisan CL, Brandini DA, Poi WR, Sonoda CK, Luvizuto $E R$, et al. Intracanal dressing and root canal filling materials in tooth replantation: a literature review. Dent Traumatol. 2012 Feb;28(1):42-8. 